\title{
An investigation on the effect of supply chain management on innovation and performance: A case study of holding firm
}

\author{
Farhad Hanifi $^{\mathrm{a}}$, Seyed Mojtaba Mahmoudzadeh ${ }^{\mathrm{b}}$ and Reza Sheikhi ${ }^{\mathrm{c}^{*}}$
}

\begin{abstract}
${ }^{a}$ Assistant Professor, Department of Management and Accounting, Tehran Central Branch, Islamic Azad University, Tehran, Iran
${ }^{b}$ Assistant Professor, Department of Management and Accounting, Allameh Tabataba'i University, Tehran, Iran

${ }^{c}$ Masters in Business Administration, Islamic Azad University, Kermanshah Branch, Kermanshah, Iran

\section{CHRON I C LE}

Article history:

Received October 28, 2013

Received in revised format

25 November 2013

Accepted 26 January 2014

Available online

January 282014

Keywords:

Supply chain management

Innovation

\section{A B S T R A C T}

This paper presents a survey on relationship between supply chain management and innovation in an Iranian holding firm in auto industry named Iran Khodro. The study designs a questionnaire in Likert scale and using random sampling technique, distributes 250 questionnaires among some managers of this holding firm. The study consists of three parts including supply chain management, innovation and organizational performance. The study uses regression technique as well as structural equation modeling and it has detected that there were some strong and positive relationship between supply chain management and innovation. In addition, the result of the survey indicates that there was some positive and meaningful relationship between supply chain management and organizational performance.
\end{abstract}

Organizational performance

\section{Introduction}

During the past few years, there have been tremendous changes on business models around the world. We see many firms with small capital and labor to create substantial value added (Bayraktar et al., 2007). These days, many high tech firms as well as knowledge-based firms have changed traditional economic definitions (Chen \& Tsou, 2006; Hervani et al., 2005). Chong et al. (2011) examined a framework, which determines the relationships between supply chain management (SCM) practices, operational performance and innovation performance of Malaysian manufacturing and service firms. The results indicated that SCM practices in both the upstream and downstream supply chain maintained a direct and significant effect on organizational and innovation performance of Malaysian firms. Innovation improvement caused by SCM also yields in better organizational performance. Their findings also disclosed that manufacturing and service firms in Malaysia did not have a substantial difference in their SCM practices.

*Corresponding author.

E-mail addresses: rezasheikhi37@yahoo.com (R. Sheikhi) 
Koh et al. (2007) determined the underlying dimensions of SCM practices and empirically examined a framework detecting the relationships among SCM practices, operational performance and SCMrelated organizational performance with special emphasis on small and medium size enterprises (SMEs) in Turkey. Based on exploratory factor analysis (EFA), SCM practices were grouped in two factors including outsourcing and multi-suppliers (OMS), and strategic collaboration and lean practices (SCLP). Quayle (2003) performed similar investigation of SCM practice in UK industrial SMEs.

\section{The proposed study}

This paper presents a survey on relationship between supply chain management and innovation in some Iranian holding firm in auto industry named Iran Khodro. The study designs a questionnaire in Likert scale and Table demonstrates details of the survey.

\section{Table 1}

The summary of different components of the survey

\begin{tabular}{|c|c|c|c|}
\hline Concept & Dimension & Component & Questions \\
\hline \multirow{6}{*}{$\mathrm{SCM}$} & \multirow{2}{*}{ Strategic } & Strategic partnership of suppliers & $1-4$ \\
\hline & & Customer relationship management & $5-6$ \\
\hline & \multirow{4}{*}{ Operative } & Information Technology & 7 \\
\hline & & Information communication & 8 \\
\hline & & Internal operations & $9-10$ \\
\hline & & Education and learning & $11-12$ \\
\hline \multirow{4}{*}{ Innovation } & \multirow{2}{*}{ Innovation in processes } & Main process such as supplement, distribution, etc. & $13-15$ \\
\hline & & Administration & $16-19$ \\
\hline & \multirow{2}{*}{ Innovation in services $\&$ products } & Basic changes & 20 \\
\hline & & Development changes & 21 \\
\hline \multirow{4}{*}{$\begin{array}{l}\text { Organizational } \\
\text { performance }\end{array}$} & \multirow{2}{*}{ Financial } & Profit & $22-25$ \\
\hline & & Sales & 26 \\
\hline & \multirow{2}{*}{ Non-financial } & Employee performance & $27-30$ \\
\hline & & Customers performance & $31-32$ \\
\hline
\end{tabular}

As we can observe from the results of Table 1, there are 32 questions, where 12 questions are associated with supply chain management, 9 questions are related to innovation issues and 11 questions are associated with organizational performance. After performing some preliminary survey, we have decided to remove question 26 from the survey leaving us to have 31 questions. In addition, Cronbach alpha for three components of the survey; namely, SCM, innovation and organizational performance were $0.841,0.838$ and 0.715 , respectively. These results confirm the overall questionnaire. There are three hypotheses associated with the proposed study of this paper as follows,

1. Supply chain management influences positively on organizational performance.

2. Supply chain management influences positively on innovation in holding company.

3. Innovation influences positively on organizational performance.

The proposed study has applied Kolmogorov-Smirnov in order to understand whether the data are normally distributed or not and the results have confirmed that all data were normally distributed. Table 2 demonstrates the results of our investigation.

Table 2

The summary of Kolmogorov-Simirnov

\begin{tabular}{|c|c|c|c|c|}
\hline & & Organizational performance & Innovation & $\mathrm{SCM}$ \\
\hline $\mathrm{N}$ & & 197 & 197 & 197 \\
\hline \multirow{2}{*}{ Normal Parameters ${ }^{\mathrm{a}, \mathrm{b}}$} & Mean & 2.3898 & 2.2598 & 2.9284 \\
\hline & Std. Deviation & .53117 & .51606 & .44424 \\
\hline \multirow[t]{3}{*}{ Most Extreme Differences } & Absolute & .058 & .078 & .096 \\
\hline & Positive & .058 & .078 & .096 \\
\hline & Negative & -.039 & -.062 & -.066 \\
\hline Kolmogorov-Smirnov Z & & 1.346 & .812 & 1.101 \\
\hline Asymp. Sig. (2-tailed) & & .053 & .525 & .177 \\
\hline
\end{tabular}




\section{The results}

In this section, we present details of our findings on testing the three hypothesis of the survey. Fig. 1 demonstrates the summary of our findings.

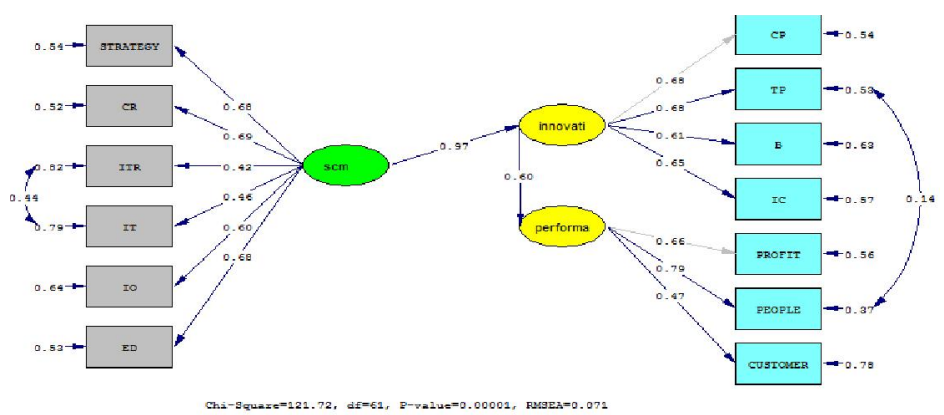

Fig. 1. The results of standard coefficients for the implementation of structural equation modeling

In addition, Table 3 demonstrates the results of statistical observations associated with the implementation of structural equation modeling.

\section{Table 3}

The summary of statistical observations associated with SEM implementation

\begin{tabular}{lccc}
\hline Attributes & Value & Desirable value & Results \\
\hline NFI & 0.93 & $>0.90$ & Desirable \\
NNFI & 0.95 & $>0.90$ & Desirable \\
CFI & 0.96 & $<0.90$ & Desirable \\
RMSEA & 0.071 & $<0.08$ & Relatively desirable \\
GFI & 0.91 & $>0.90$ & Desirable \\
AGFI & 0.87 & $>0.90$ & Relatively desirable \\
RMR & 0.029 & Close to zero & Desirable \\
IFI & 0.96 & $>0.90$ & Desirable \\
\hline
\end{tabular}

The results of Table 3 confirm the overall model and allow us examine the hypotheses of this survey. Based on the results of Fig. 1, there is a positive and meaningful relationship from SCM toward innovation $(\beta=0.97)$. In addition, there is a positive and meaningful relationship from innovation toward organizational performance $(\beta=0.6)$. Finally, SCM influences organizational performance through innovation. These results confirm three hypotheses of the survey.

We have also performed three regression techniques to examine three hypotheses of the survey. The first regression analysis investigates the relationship between organization performance and innovation and Table 4 shows details of the results.

\section{Table 4}

The summary of regression analysis between organization performance and Organizational performance

\begin{tabular}{ll|lllllll}
\hline Hypothesis & Independent variable & Dependent variable & Correlation ratio & $\mathrm{R}^{2}$ & $\mathrm{t}$-student & Sig. & Result \\
\hline First & CRM & $\begin{array}{l}\text { Organizational } \\
\text { performance }\end{array}$ & 0.32 & 0.134 & 5.597 & 0.000 & Confirmed \\
\hline
\end{tabular}

As we can observe from the results of Table 4, there is a meaningful relationship between CRM and organizational performance. Similarly, Table 5 demonstrates the summary of our findings on testing the relationship between CRM and Innovation and Table 5 shows details of our findings.

\section{Table 5}

The summary of regression analysis between organization performance and innovation

\begin{tabular}{llllllll}
\hline Hypothesis & Independent variable & Dependent variable & Correlation ratio & $\mathrm{R}^{2}$ & t-student & Sig. & Result \\
\hline Second & CRM & Innovation & 0.778 & 0.605 & 17.266 & 0.000 & Confirmed \\
\hline
\end{tabular}


As we can observe from the results of Table 5, there is a meaningful relationship between CRM and Innovation. Finally, Table 6 summarizes the results of our findings on testing the third hypothesis of the survey on relationship between Innovation and organizational performance.

\section{Table 6}

The summary of regression analysis between organizational performance and innovation

\begin{tabular}{lllllllll}
\hline Hypothesis & Independent variable & Dependent variable & Correlation ratio & $\mathrm{R}^{2}$ & t-student & Sig. & Result \\
\hline Third & $\begin{array}{l}\text { Organizational } \\
\text { performance }\end{array}$ & Innovation & 0.435 & 0.189 & 6.745 & 0.000 & Confirmed \\
\hline
\end{tabular}

As we can observe from the results of Table 6, there is a meaningful relationship between organizational performance and Innovation. Finally, Table 7 demonstrates the results of relationship between various components in terms of their effects and ranking.

\section{Table 7}

The summary of ranking various factors

\begin{tabular}{ccccc}
\hline \multirow{2}{*}{ Rank } & Independent variable & Dependent variable & Correlation & $\begin{array}{c}\text { Coefficient of } \\
\text { determination }\end{array}$ \\
\hline 1 & CRM & Innovation & 0.778 & 5.6 \\
2 & Innovation & Organizational performance & 0.435 & 9.18 \\
3 & CRM & Organizational performance & 0.32 & 4.13 \\
\hline
\end{tabular}

Based on the results of Table 7, there is a strong relationship between CRM and Innovation, a moderate and positive relationship between Innovation and organizational performance and fair relationship between CRM and organizational performance.

\section{Conclusion}

In this paper, we have presented an empirical investigation to study the relationship between customer relationship management and having innovative ideas in one of Iranian automakers. The study has accomplished structural equation modeling as well as regression analysis to examine the hypotheses of the survey. Based on the results of this survey, we have concluded that there was a strong relationship between CRM and Innovation, a moderate and positive relationship between Innovation and organizational performance and fair relationship between CRM and organizational performance.

\section{References}

Bayraktar, E., Demirbag, M., Koh, S. C., Tatoglu, E., \& Zaim, H. (2009). A causal analysis of the impact of information systems and supply chain management practices on operational performance: evidence from manufacturing SMEs in Turkey. International Journal of Production Economics, 122(1), 133-149.

Chen, J. S. J., \& Tsou, H. T. (2006). Information technology adoption for service innovation practices and competitive advantage: the case of financial firms. Information Research, 12(3), 7.

Chong, A. Y., Chan, F. T., Ooi, K. B., \& Sim, J. J. (2011). Can Malaysian firms improve organizational/innovation performance via SCM?. Industrial Management \& Data Systems, 111(3), 410-431.

Hervani, A. A., Helms, M. M., \& Sarkis, J. (2005). Performance measurement for green supply chain management. Benchmarking: An International Journal,12(4), 330-353.

Koh, S. L., Demirbag, M., Bayraktar, E., Tatoglu, E., \& Zaim, S. (2007). The impact of supply chain management practices on performance of SMEs. Industrial Management \& Data Systems, 107(1), 103-124.

Quayle, M. (2003). A study of supply chain management practice in UK industrial SMEs. Supply Chain Management: An International Journal, 8(1), 79-86. 